\title{
Extending PR's critical conversations with advertising and marketing
}

\section{Ampliando as conversações de RPs com a Publicidade e o Marketing}

Clea D. Bourne

\begin{abstract}
This article provides a deeper understanding of the public relations field by exploring the struggles of its closest professional neighbours: advertising and marketing. The article casts these three fields as distinct professional projects, using literature from Critical Advertising, Critical Marketing, Critical PR and sociology of the professions to examine areas of distinction, tension and convergence as advertising, marketing and PR struggle for dominance over one another.
\end{abstract} Key words: Advertising, marketing, public relations, convergence, professions

Resumo Este artigo pretende aprofundar o entendimento sobre o campo das Relações Públicas explorando os embates com seus vizinhos profissionais mais próximos - publicidade e marketing. O artigo elenca estes três campos como projetos profissionais distintos, e faz uso da literatura da Crítica da Publicidade, da Crítica do Marketing e da Crítica das Relações Públicas e a sociologia das profissões para examinar áreas de distinção, tensão e convergência como publicidade, marketing e relações públicas no embate entre eles.

Palavras-chave: Publicidade, marketing, relações públicas, convergência, profissões

\footnotetext{
${ }^{1}$ Goldsmiths, University of London, UK.

E-mail: c.bourne@gold.ac.uk
} 
Advertising, marketing and public relations (PR) have experienced phenomenal occupational growth throughout the past century. In large, mature markets the three fields have evolved as separate specialisms, disciplines and professional projects. From the outside looking in, few may regard advertising, marketing and PR as separate. This is particularly the case in small and developing markets, where practitioners may work in PR, advertising and marketing. Indeed, in an increasingly globalised and digital world, distinctions between advertising, marketing and PR are often blurred and perceived as part of the same set of advanced techniques in modern commercial culture.

From a critical perspective, advertising, marketing and PR can be seen collectively as a set of practices and discourses that have helped to constitute and shape modern social relations. Yet the evolution of the three fields as separate disciplines is an important subject for the critical lens. This is because the emergence of distinctions between the fields is a story of inter-professional tensions as advertising, marketing and PR struggle for dominance over one another. Practitioners within the respective fields have also struggled to formalise their managerial status and establish themselves as trusted experts for client organisations.

Professional tensions between the fields are also visible in academic discourse, which has played an accompanying role in formalising advertising, marketing and PR practices. Nearly 40 years ago, the well-known marketing theorist, Philip Kotler, writing with Mindak (1978), questioned whether PR and marketing would evolve as "partners or rivals," critiquing a perceived lack of scientific discipline within the public relations field. A decade later, Kotler, together with other US marketing scholars, met their PR counterparts at a colloquium designed to mark out conceptual domains and "operational turf" between the disciplines of PR and marketing (BROOM et al, 1991). Similarly, influential theorists in Critical Marketing are inclined to regard both advertising and PR as "aspects" or "sub-fields" of a general marketing discourse (SKÅLÉN et al, 2008). Some critical advertising/marketing theorists dismiss the very notion of "Critical PR," arguing either that PR is merely part of 
advertising or marketing - and can only be critiqued as a subset of these activities - or that PR itself is so malodorous that critiquing PR activities would be unproductive, since PR ought not to exist.

My own critical efforts have no such cynical outlook, and are driven instead by a quest for new understandings of PR practices and techniques by exploring PR's disciplinary struggles with its nearest professional counterparts. If reconfiguring PR means changing its conversations (MCKIE and MUNSHI, 2007), then PR's conversations can be expanded productively by throwing open the windows currently separating the emerging disciplines of Critical Advertising, Critical Marketing and Critical PR. In this article I therefore position advertising, marketing and PR as distinct professional projects, in order to explore the tensions, struggles and overlaps between PR and its closest professional neighbours.

\section{Genesis of critiques on advertising and marketing}

Whereas Critical PR is only just developing as an academic field, critical perspectives of advertising and marketing have existed at least since the 1970s. The trajectory of research has also differed; in part because advertising and marketing often evolved in different university departments, and in part because the scholars who critique advertising and marketing wear their critical hats at different "angles." Scott (2007, p. 4) explains this by pointing to the different ways in which the term "critical" is construed across advertising and marketing literature. For some advertising and marketing scholars "critical," for example, means "interpretive" or "qualitative," while others use "Critical" with a capital "C," explicitly meaning "Marxist." Others adopt a "critical" stance on larger social issues - such as globalisation or environmentalism - using advertising or marketing for socially progressive purposes. Finally, there are "critical" theorists who choose to resist more mainstream approaches to the study of advertising and marketing (SCOTT, 2007), as is true of much Critical PR scholarship. 
Earlier critical advertising and marketing work was dominated by literary critique, using semiotics, rhetoric, poststructuralism and postmodernism to deconstruct the products of advertising and marketing as forms of representation (SCOTT, 2007, p. 5). Some of this work, Scott maintains, has become canonical, including John Berger's (1973) Ways of Seeing and Judith Williamson's (1979) Decoding Advertisements. Williamson's classic, in particular, posited that consumers could not escape advertising's false meanings; that advertising had "a life of its own," persuading consumers to buy goods against their real class interests (WILLIAMSON, 1979, p. 13). These and many other authors offered an analytical view on the "pervasiveness of imagery in late twentieth-century culture” (NAVA, 1997, p. 47). The combined perspectives resulting from this earlier work gave rise to a new sub-discipline, "cultural studies," typically housed in English departments or communications schools (SCOTT, 2007).

Cultural Studies explored the "culture industries" and processes of enculturation, taking in all those institutions and industries involved in some way with the production of popular culture (ELLIS et al, 2011, p. 43). Advertising and marketing were positioned as a key site of negotiation between economic and cultural spheres (LEISS et al, 2005, p. 15), with advertising and marketing practitioners being cast as cultural intermediaries educating the masses in the pleasures of consumption (WILLMOTT, 1999, p. 208). Other early critical scholarship adopted postmodernist perspectives, with successive studies focused on themes such as the fragmentation of markets into ever-smaller segments, including the supposed "one-to-one marketing"; hyperreality - exemplified by the many studies of shopping centres, the fantasy worlds of theme parks; the "pretence" of typical service encounters in which customer service representatives deliver rote responses as they follow preordained scripts; and pastiche television commercials and display advertising represented by self-referentiality (SKÅLÉN et al, 2008, p. 10).

Some of these critical approaches proved questionable, particularly as it became apparent that Cultural Studies was providing a way for 
many advertising and marketing academics to legitimise their discipline in relation to campus radicalism and the "culture wars" of the 1990s (ARVIDSSON, 2008). Some early critical advertising and marketing scholarship promoted Marxist political agendas, thinly disguised as research (SCOTT, 2007). Cultural Studies was so often characterised by a "Critical" perspective that, by the 1990s, the two had become synonymous; viewed by a new generation of critical theorists as too despairing in tone and too dogmatic in approach (SCOTT, 2007).

Revisionist scholars (ARVIDSSON, 2008; NAVA, 1997; SCOTT, 2007) argue that earlier critical work portrayed people primarily as "consumers," thus marginalising other subjectivities such as citizenship. Meanwhile, those same consumers - particularly women - were too often portrayed as weak, malleable and unable to resist so-called neoliberal ideologies imposed by the marketing-media-branding complex (HACKLEY, 2009). Early critical scholarship is also accused of focusing relentlessly on industrial capitalism as the major source of oppression, thus failing to encompass other forms of economic organisation, particularly in more traditional agrarian societies. One exception to these revisionist critiques, concedes Scott (2007), may be the emancipatory efforts of Cultural Studies regarding cultural representations of women.

Leiss et al.(2005) further contend that earlier debates about advertising and marketing were overly focused on consumer markets and advertising/marketing's most visible outputs, such as display and television advertising. In doing so, earlier critical work helped mask a wide range of "hidden" techniques, from sales and marketing "control technologies" defined by their very invisibility (e.g. concealed microphones and cameras, or mystery shoppers) to disciplinary practices such as compensating or setting sales quotas - practices equally invisible to the onlooker and thus never framed as forms of power (SKÅLÉN et al, 2008). PR scholarship has been similarly critiqued for bypassing more hidden activity such as lobbying in favour of visible outputs such as media relations. Likewise, B2B (business-to-business) marketing remained under-represented in earlier critical scholarship despite its size 
and importance (ELLIS et al, 2011). The absence of formal industry-wide training and qualifications in advertising and marketing also aides the "invisible" history surrounding these occupations, enabling myths and oral stories to predominate (LEISS et al, 2005; LIEN, 1997; LURY, 1994).

\section{Advertising, marketing and PR - assuaging producer anxiety}

As critical perspectives of advertising and marketing have evolved, authors have increasingly unmasked the activity taking place "behind the scenes" of advertising and marketing work.

These behind-the-scenes studies include the exploration of efforts to professionalise the fields (CHALMERS, 2001; LIEN, 1997; WILLMOTT, 1999). I will integrate some of this literature with similar discussions in Critical PR and with broader sociological perspectives of professionalisation in order to yield new understandings of all three fields vis-à-vis one another. I begin by positioning advertising, marketing and PR as "entrepreneurial professions" or "expert labour" (MUZIO et al, 2008, p. 25). Entrepreneurial professions have borrowed several features from traditional professions such as medicine or law, but, as Muzio et al.(2008) point out, this is largely a symbolic exercise. Advertising, marketing and PR have neither the professional credentials nor other independent sources of knowledge, remaining largely open and governed by market mechanisms. Their professional associations are embryonic, with no mandatory membership or credentials, while minimal special education is required to become a practitioner in any of the three fields (MUZIO et al, 2008, p. 4).

As a result, de facto control over the advertising, marketing and PR professions is weak - deliberately so, argue Muzio et al. (2008), because entrepreneurial professions are highly responsive to the organisations they serve. Not only are such professions active in the construction of knowledge through their use of language and client relationship skills, 
they are also continually developing new forms of knowledge together with different methods for its production, organisation and delivery, adopting "radically different strategies and organisational configurations" as needed (MUZIO et al, 2008, p. 4). But why would promotional professions deliberately undermine their own professional projects in this way? One answer arises in scholarship which personifies the corporate body, highlighting the anxieties plaguing contemporary client organisations.

Writing about advertising and marketing, Lury and Warde (1997, p. 487) contend that the constant shifting and changing in these professions has been in response to "producer anxiety or uncertainty" (p. 87). Organisations that seek advertising and marketing counsel have a perpetual problem - that of finding sufficient consumers for the volume of goods they produce - knowing that they cannot force people to buy their products, services or ideas now or in the future (LURY and WARDE, 1997). Any legitimacy possessed by advertising and marketing professionals has therefore evolved through practitioner efforts to assuage producer anxiety by promoting advertising and marketing as the appropriate disciplines for "guiding, controlling, influencing and predicting what consumers will be prepared to buy" (LURY and WARDE, 1997, p. 92). Similarly, Marchand (1998) argues that an array of twentieth-century PR initiatives was undertaken by client organisations in a quest to create a "corporate soul." Corporates were intent on legitimising newly amassed power, not just to others but to themselves. PR techniques were consequently used to assuage the anxiety of corporations keen to restore their social role in the eyes of the public, and to be accepted members of the larger community by establishing the "rightness" of their expansion activities (CHRISTENSEN et al, 2008; MARCHAND, 1998). Hence, advertising, marketing and PR are located as part of a growing number of professions attempting to assuage decision-makers' anxieties by "managing uncertainty, calculating probability and minimising risk” (LURY and WARDE, 1997, p. 99). 
Contemporary client organisations are therefore likely to resist professionalisation strategies (LURY and WARDE, 1997) adopted by advertising, marketing and $\mathrm{PR}$, stripping these forms of professional advice of their moral authority and recasting the fields as a technical resource or commodity (LURY and WARDE, 1997; MUZIO et al, 2008). Broadly speaking, organisations, regardless of whether they are in the private, public or not-for-profit sectors, are defined by the overarching need to produce reliable, stable alliances with their key stakeholders (LIEN, 1997). The implications for advertising, marketing and PR's professional projects are stark. Whereas traditional professions are customarily understood as producing their own ideology, which in turn establishes their professional status, universal validity and expertise (LARSON, 2012), the combined critical literatures suggest that it is organisational ideology that has produced advertising, marketing and PR. This represents a "reverse" ordering of professionalisation in which professional development is shaped not by the professions but by the organisations they serve (MUZIO et al, 2008). As a result, advertising, marketing and $\mathrm{PR}$ are forced into a never-ending pursuit of legitimation strategies to help them remain relevant to client organisations. This never-ending pursuit for relevance further defines the interprofessional tensions within and between the three promotional fields.

\section{Advertising, marketing and PR - legitimation strategies}

The contemporary anxieties "experienced" by client organisations are defined by a constant series of challenges, from entering new markets to holding on to customers in existing ones - from adopting new technologies and media channels to meeting new regulatory requirements. What then are the legitimation strategies developed by advertising, marketing and PR? And how successful have these strategies been in assuaging organisational anxieties? Across the promotional professions, a significant portion of expertise are based on social capital, informal knowledge, soft skills and emotional labour, as well as formal, scientific and managerial knowledge more closely associated with professional influence. 
The social capital underlying the promotional fields is complex. In Western Europe and North America, for example, the most powerful promotional roles tend to be white, male and middle class (EDWARDS, 2011; LURY, 1994; NIXON, 2003). Applicants to advertising, marketing and $\mathrm{PR}$ are, today, typically university educated, but the type of degree is less important than the associated peer-group influence, since many promotional practitioners come to rely on their social networks for professional advancement. This is particularly true for consultancy-based practitioners for whom new business contacts are professional "currency." The "white, male, middle-class" profile is not replicated globally, of course, but what remains important is that the promotional professions replicate, as far as possible, the social capital of their client organisations. For this reason, where diversity may have become an organisational imperative in some fields, for promotional professions, diversity with respect to gender, race or class is "useful" only insofar as it allows client organisations to engage better with external audiences (EDWARDS, 2011).

Informal knowledge is naturally hard to pin down due to deliberate efforts to separate personal knowledge from professional identity (LIEN, 1997). Promotional practitioners bring a range of pertinent knowledge to their daily tasks, gleaned as citizens, consumers and other subjectivities. Yet, as Lien (1997) argues, such a competence remains largely invisible or unarticulated. Other forms of informal knowledge are elusive, known only to certain professionals. Advertising, for example, has engendered a "cult of creativity" and mythology of "artistry plus genius," in which creative directors - typically male - wield elite status and influence (McSTAY, 2010; NIXON, 2003). Client organisations value creativity for its "newness," its ability to break new boundaries and establish new genres (NIXON, 2003). Through creativity, advertising professionals are able to assuage client anxiety by meeting the demand for ever-more sophisticated campaigns in highly competitive markets (FAULCONBRIDGE et al, 2011). Yet advertising's supposed dominance over creativity may have infringed on PR territory in some contexts. Contemporary debates in the 
PR press trade suggest that, in a battle for market share, global PR firms are recolonising marketing communications by reclaiming "creativity" as a public relations specialism - hiring creative directors and "creative catalysts," and entering creative competitions that were previously the domain of advertising (ROGERS, 2014).

All three promotional professions rely heavily on soft skills such as communication. Lien (1997) points out that this is even true of marketing, despite the profession's efforts to privilege its "hard" skill sets. For Lien (1997), marketing is communicative on two levels: first, by translating and interpreting consumers' needs and preferences; second by selecting the characteristics of a product (or service), then visualising and textualising these characteristics for target groups. Such soft skills are often part of emotional labour - that is the management of "feeling" in the workplace (HOCHSCHILD, 2012). In PR, for example, Yeomans (2010, p.6) points to the emotional labour of managing client relationships, earning trust and respect by "making the client happy." Many PR practitioners also cater to journalists as important stakeholders, where emotional labour involves not upsetting or alienating journalists, and not wasting their time by promoting irrelevant stories (YEOMANS, 2010).

\section{Scientific/managerial discourse}

Despite the importance of informal knowledge, advertising, marketing and PR have all come to be dominated by a managerial discourse in which formal scientific knowledge confers the most power (HACKLEY, 2009). Scientific knowledge relies on credibility gained through the use of epistemology, collation of facts and application of scientific methods (WILLMOTT, 1999). The need to recast promotional work as scientific and managerial has come about partially from a sense of intellectual inferiority experienced by promotional professionals (LURY and WARDE, 1997), but also the need to vie for credibility against the claims of other more established management disciplines such as accounting or operations. Promotional professionals therefore engage in a "Darwinian 
corporate game" (Pitcher, 2002, p. 62) to outdo each other in managerial and technical expertise.

Marketing has been particularly successful in systematising formal, technical knowledge, having itself evolved as a branch of applied economics concerned with the distribution of goods and buying behaviour (HACKLEY, 2009). Marketing then replaced the economists' assumption of "perfect information in competitive markets" with theories of advertising persuasion drawing from social psychology and other fields (HACKLEY, 2009, p. 117), while also adopting approaches from engineering and sales management (SKÅLÉN et al, 2008). With concepts such as the Unique Selling Proposition, the "4Ps" - Product, Price, Place and Promotion (later extended to the "7Ps") - market segmentation and Integrated Marketing Communication (IMC) became widely used terms, denoting the success of marketing's managerial discourse. Such terms appeal to client organisations not just because they provide a well-defined, theorised set of practices, but because of their inherent promise of progress and rationality (CHRISTENSEN et al, 2008). The 4Ps checklist offers clients a sense of engineering precision, while other terms such as B2B and CRM (Customer Relationship Management) have introduced further specialisation in marketing practice, creating new, distinct sub-fields of expertise. Some of these scientific methods will now be examined in further detail.

\section{Market segmentation and surveillance}

Perhaps the most powerful set of legitimation strategies used by promotional professions are those that manipulate stakeholders, producing subjectivities and binding targeted groups more tightly to organisations (SKÅLÉN et al, 2008). Market segmentation and surveillance, for example, require researchers to produce contextualised knowledge regarding the sorts of products or services an organisation's customers want (LURY and WARDE, 1997). By tracking consumers, market segmentation acts as a "vast panoptic system of observation and social control" (BROWNLIE et al, 1999, p. 8). Methods of marketing surveillance 
have intensified dramatically since the widespread introduction of digital technologies. Digital advertising is a prime example. Much of it is unbranded, like classified advertising, and based on algorithms that aim to engender relevance to the consumer (McSTAY, 2010). It is therefore "hidden" from view, unlike more creative forms of display advertising that featured heavily as exemplars of visual representation in earlier Cultural Studies work. Dataveillance produced through advertising algorithms invoke Foucauldian views of discipline, McStay (2010) argues, involving surveillance, individuation and behavioural correction, creating docile bodies that are more powerful yet easier to direct and subjugate, because they are more calculable and thus "easier to know."

\section{Relationship management paradigm}

Also connected with surveillance techniques is relationship management, a parallel paradigm in public relations and marketing. As an orthodoxy, the relationship paradigm has defined the formalisation of PR and marketing professions, particularly in mature markets. Here, PR and marketing have been compelled not only to promote products, services, people or ideas to stakeholders as counterparts in an exchange, but to "engage" with stakeholders as long-term partners - even a "spouse" (GUMMESON, 2002), in the hope that resulting long-term relationships will secure profits and recognisable gains. The "relationship management" orthodoxy is further driven by the imperative to create value during the consumption of goods or services. In service-oriented firms, value creation is mutually created with the customer through long-term relationships (SKÅLÉN et al, 2008). The customer becomes the core of the organisation's strategic process. Any occupation able to govern this "ultimate organisational imperative" (SKÅLÉN et al, 2008) gains a strategic role within the firm through expertise on key stakeholder relations. For this reason, relationship marketing and relationship management have become important joint sources of power through which PR and marketing simultaneously "legitimise" their managerial expertise (SKÅLÉN et al, 2007). 
The "relationship" paradigm has contributed to ever-more "complex methods of observation" (FOUCAULT, 1989 [1963]), a form of "gaze" over individuals and organisations. In marketing, the relationship paradigm has been coupled with technologies such as Customer Relationship Management systems. Similar forms of "gaze" are apparent in PR practice, where a plethora of indices and surveys are conducted by national and global PR consultancies in an effort to measure trust, goodwill and mutual understanding among key stakeholder groups (BOURNE, 2013).

Managerial discourses in advertising, marketing and PR are replete with issues - the promotional fields are accused, for example, of an over-reliance on bad science, "made-up" metrics and counterproductive scientism (BROWNLIE et al, 1999; TUROW, 2011). Furthermore, managerial discourses are often gendered discourses, reproducing technical expertise as a central defining feature of the senior male professional's role, while relegating more routine tasks and much of the emotional labour to junior, often female, personnel (CHALMERS, 2001). Ultimately, while managerial discourses may articulate promotional activity on behalf of large, complex organisations, they do not adequately express the nature of wide-ranging promotional activity undertaken on behalf of small, ephemeral or non-corporate entities such as activist groups or one-man bands (McKIE and MUNSHI, 2007).

\section{Globalising}

The final legitimation strategy reviewed here is globalising, for which there is an ever-increasing reliance on advertising, marketing and PR to develop, spread and sustain new markets for products and services (FAULCONBRIDGE et al, 2011). The need to globalise markets as a means of assuaging corporate anxiety has changed the shape of the promotional industries. All three have experienced convergence, with an increasing number of national consultancies now acquired by large, global groups with phenomenal reach. Global communication firms have real clout with client organisations because they are in a position to 
employ all of the preceding legitimation strategies, formal or informal, on a global dimension, thus achieving efficiencies of scale. Global consultancies can also act quickly, offering campaigns and other services that mimic "just-in-time" manufacturing processes. A new advertising campaign can, for example, be tailored not just to specific consumers, but also to their "reactions and interpretations of recent global- or country- or region-specific events" (FAULCONBRIDGE et al, 2011, p. 13), with campaigns appearing almost immediately after key political and sporting mega-events, attempting to reflect consumer responses to them.

Predictably, the globalising of promotional activity has been heavily censured by critical scholars across advertising, marketing and PR (LEISS et al, 2005; McKIE and MUNSHI, 2007; WITKOWSKI, 2008), particularly since the promotional fields have provided strategies and tactics for spreading a dominant world culture via an "influx of ideas, values, products, and lifestyles from the rich countries," ultimately debasing developing countries' cultures (WITKOWSKI, 2008, p. 220). Meanwhile, the success of global communication firms in exporting the "ideas, images, products, services and brands" of multinational organisations (ELLIS et al, 2011, p. 221) only intensifies critiques of global advertising, marketing and $\mathrm{PR}$ as forms of cultural imperialism.

\section{Struggles within and between the fields}

The struggles within and between advertising, marketing and PR can be further seen within the context of broader professional struggles. Advertising has, for example, found it necessary to converge with or protect itself from specialisms such as media buying, web design and social media campaigning. The past 25 years have seen the rise of media buying agencies, together with an array of satellite companies providing technology and data (TUROW, 2011). Whereas media buying was once a "backwater" of advertising, its hegemony over digital technologies has now closed this field of knowledge to those in the upper reaches of advertising who lack the technical knowledge to grasp the nature of this 
specialism (TUROW, 2011). Digital media has also increased blurred lines between advertising and marketing, with websites providing an excellent example of convergence since they act as both web advertising as well as a "virtual shop window" for marketing activity (McSTAY, 2010, p. 116).

Whereas PR has "divorced" its professional project from fields such as journalism or

advertising (McKIE and MUNSHI, 2007, citing TOLEDANO, 2005), PR has also struggled with colonisation by the marketing discipline, which increasingly includes activities traditionally ascribed to PR such as fostering and maintaining goodwill among relevant stakeholders (CHRISTENSEN et al, 2008). Jurisdictional threats to PR also come from human resources, in-house legal counsel, investor relations and risk management professionals, all of whom are concerned with issues of management and reputation management. More recently, the PR profession has itself pointed to management consultancy and professional services as the disciplines that are now in the best position to "eat PR's lunch” (PRCA, 2012). As with advertising's relationship with media buying, PR also struggles to maintain its professional identity against its own "hybrids." Corporate communications has, for example, established itself as a managerial vision that promises to establish and maintain a unified organisational identity by regulating and controlling all communicative activity, encapsulating not just PR, but advertising and marketing, as well as human resources (CHRISTENSEN et al, 2008).

Of the three fields, advertising and PR may encounter greater jurisdictional threats, while marketing is by far the greatest aggressor. Indeed, marketing discourses frequently explicate marketing as warfare through notions of "competition," "conquest" and the importance of "capturing market share” (LIEN, 1997). Marketing's assertive approach has not only achieved greater success in deepening the field's expertise through scientific and managerial discourses, but has also increased its status and influence by broadening its relevance and reach (WILLMOTT, 1999). Whereas marketing initially evolved as a professional jurisdiction by 
“divorcing” itself from sales (CHALMERS, 2001; WILLMOTT, 1999), it has since gone on to contest other fields - not just advertising and PR - by reconstructing and stretching established definitions of marketing. The marketing concept has been universalised, extending from consumer markets to wholesale markets, as well as the public and not-for-profit sectors (HACKLEY, 2009). While within organisations, marketing's "exceptionalism" has thwarted the jurisdictional roles of accountants, engineers, HR managers and project managers (WILLMOTT, 1999).

Marketing's efforts to "universalise" its expertise has meant that, particularly in service organisations, "everyone is a marketer now," with front-line employees considered as part-time marketers, albeit with ill-defined marketing roles (SKÅLÉN et al, 2008). On the one hand, the concept of part-time marketer is "ingenious" according to Skålén et al. (2008), who argue that it resolves potential conflict between marketing and operational functions by rearticulating marketing as a "cross-functional dimension" rather than as a threat to, or replacement of, other functions (SKÅLÉN et al, 2008, p. 134). By contrast, Brownlie et al (1999, p.186) describe this universalising effect of marketing as a "bridge too far." The broader marketing becomes, they argue, the further it thrusts itself into domains "for which it is ill equipped," and the less exclusive its expertise are - a view which sounds a warning for other fields, including public relations.

\section{Conclusion}

This article has presented a sample of arguments from Critical Advertising and Critical Marketing scholarship, through which the public relations discipline might contextualise its own emerging critical perspectives. It is useful, for example, to explore PR's professional project, not in isolation, but as part of a wide range of entrepreneurial professional projects constantly struggling to make themselves relevant to decision-makers. This helps to illuminate some of the questions occupying the time of PR scholars, such as the continuously evolving nature of PR definitions and expertise. An exploration of other bodies of critical literature 
further suggests that the ebbs and flows constantly erode and reshape PR's jurisdiction and professional identity, which are by no means unique to the field.

Exploring the critical perspectives generated in other disciplines is also a reminder that PR scholarship must simultaneously embrace theory, including critical theory, while remaining suspicious of it (MACLARAN and STEVENS, 2008). Theory cannot only broaden PR's development, it can skew perspectives, encouraging the sort of insularity that defined certain corners of PR scholarship in the past. Exploring Critical Advertising and Critical Marketing is also a reminder to PR scholars that PR cannot solve all the problems of organisations or societies, since contemporary organisations and cultures are diverse and dissimilar. Further bodies of critical work also serve as a cue to PR scholars to safeguard against using critical perspectives to "suppress, silence and devalue other theoretical voices" (MACLARAN and STEVENS, 2008, p. 347). Instead, following Maclaran and Stevens, PR scholars may engage with and theorise the human side of PR, while asking "who is marginalised in our field?" and "who does PR dominate or silence?"

\section{References}

ARVIDSSON, A. The function of cultural studies in marketing. In: TADAJEWSKI, M.; BROWNLIE, D. (Eds.). Critical marketing: Issues in contemporary marketing. Chichester, UK: Wiley \& Sons, 2008. p. 329-344.

BERGER, J. Ways of seeing. London: Penguin Classics, 2008 [1973].

BOURNE, C. Reframing trust, power and public relations in financial services. Public Relations Inquiry, 2 (1), p. 51-77, 2013.

BROOM, G. M.; LAUZEN, M. M.; TUCKER, K. Public relations and marketing: Dividing the conceptual domain and operational turf. Public Relations Review, 17 (3), p. 219-225, 1991.

BROWNLIE, D.; SAREN, M.; WENSLE, R.; WHITTINGHAM, R. (Eds.). Rethinking marketing. London: Sage Publications, 1999.

CHALMERS, L.V. Marketing masculinities. Westport, CT: Greenwood Press, 2001. 
CHRISTENSEN, L. T.; MORSING, M.; CHENEY, G. Corporate communications: Convention, complexity and critique. London: Sage Publications, 2008.

EDWARDS, L. Diversity in public relations. In: ; HODGES, C. (Eds.). Public relations, society and culture. Abingdon, UK: Routledge, 2011. p. 75-89.

ELLIS, N.; FITCHETT, J.; HIGGINS, M.; JACK, G.; LIM, M.; SAREN, M.; TADAJEWSKI, M. Marketing: A critical textbook. London: Sage Publications, 2011.

FAULCONBRIDGE, J.; BEAVERSTOCK, J. V.; NATIVEL, C.; TAYLOR, P. J. (Eds.). The globalization of advertising. Abingdon, UK: Routledge, 2011.

FOUCAULT, M. The birth of the clinic. Abingdon: Routledge Classics, 1989 [1963].

GUMMESSON, E. Total relationship marketing. 2. ed. London: Butterworth-Heinemann, 2002.

HACKLEY, C. Marketing: A critical introduction. London: Sage Publications, 2009. HOCHSCHILD, A. The managed heart: Commercialization of human feeling. Berkeley, CA: University of California Press, 2012.

KOTLER, P.; MINDAK, W. Marketing and public relations. Journal of Marketing, 42 (4), p. 13-20, 1978.

LARSON, M. S. The rise of professionalism. Piscataway, NJ: Transaction Publishers, 2012.

LEISS, W.; KLEIN, S.; JHALLY, S.; BOTTERILL, J. Social communication in advertising. Abingdon, UK: Routledge, 2005.

LIEN, M. E. Marketing and modernity. New York: Bloomsbury Academic, 1997.

LURY, A. Advertising: Moving beyond the stereotypes. In: KEAT, R.; WHITELY, N.; ABERCROMBIE, N. (Eds.). The authority of the consumer. London: Routledge, 1994. p. 84-93.

LURY, C.; WARDE, A. Investments in the imaginary consumer. In: NAVA, M.; BLAKE, A.; MACRURY, I.; RICHARDS, B. (Eds.). Buy this book: Studies in advertising and consumption. London: Routledge, 1997. p. 87-102.

MACLARAN, P.; STEVENS, L. (2008). Thinking through theory. In: TADAJEWSKI, M.; BROWNLIE, D. (Eds.). Critical marketing: Issues in contemporary marketing. Chichester, UK: Wiley \& Sons, 2008. p. 345-361.

MCKIE, D.; MUNSHI, D. Reconfiguring public relations. Abingdon, UK: Routledge, 2007.

MCSTAY, A. Digital advertising. London: Palgrave Macmillan, 2010.

MARCHAND, R. Creating the corporate soul: The rise of public relations and corporate imagery in American big business. Berkeley, CA: The University of California Press, 1998.

MUZIO, D.; ACKROYD, S.; CHANLAT, J.-F. Introduction: Lawyers, doctors and business consultants. In: (Eds.). Redirections in the study of expert labour. Basingstoke, UK: Palgrave Macmillan, 2008. p. 1-30.

NAVA, M. Framing advertising: Cultural analysis and the incrimination of visual texts. In: __.; BLAKE, A.; MACRURY, I.; RICHARDS, B. (Eds.). Buy this book: Studies in advertising and consumption. London: Routledge, 1997. p. 34-50. 
NIXON, S. Advertising cultures. London: Sage Publications, 2003.

PITCHER, G. The death of spin. Chichester, UK: Wiley \& Sons, 2002.

PRCA. The future of the PR industry. London: Public Relations Consultants Association, 2012.

ROGERS, D. Cannes' crowning glory. PR Week, p. 46-48, jul.-aug. 2014.

SCOTT, L. M. Critical research in marketing: An armchair report. In: SAREN, M.; MACLARAN, P.; GOULDING, C.; ELLIOTT, R.; SHANKAR, A.; CATTERALL, M. (Eds.). Critical marketing: Defining the field. Burlington, MA: Butterworth-Heinemann, 2007. p. 3-17.

SKÅLÉN, P.; FOUGÈRE, M.; FELLESSON, M. Marketing discourse: A critical perspective. Abingdon, UK: Routledge, 2008.

TOLEDANO, M. Public relations in Israel: the evolution of public relations as a profession in Israel's changing political, socio-cultural and economic environment. Paris: University of Paris 8, 2005. (Unpublished thesis).

TUROW, J. The daily you: How the new advertising industry is defining your identity. London: Yale University Press, 2011.

WILLIAMSON, J. Decoding advertisements. London: Marion Boyar, 1979.

WILLMOTT, H. On the idolization of markets and the denigration of marketers. In: BROWNLIE, D.; SAREN, M.; WENSLEY, R.; WHITTINGHAM, R. (Eds.). Rethinking marketing. London: Sage Publications, 1999. p. 205-222.

WITKOWSKI, T. H. Antiglobal challenges to marketing in developing countries. In: TADAJEWSKI, M.; BROWNLIE, D. (Eds.). Critical marketing: Issues in contemporary marketing. Chichester, UK: Wiley \& Sons, 2008. p. 211-244.

YEOMANS, L. Soft sell? Gendered experience of emotional labour in UK public relations firms. Prism 7(4), p. 1-14, 2010. Retrieved from: http//www.prismjournal.org.

\section{About the author}

Lecturer and researcher in public relations, advertising and marketing, following more than 20 years as a professional in these fields. Specialties: Research interests include public relations and the production of trust in global financial markets; as well as critical and postcolonial perspectives on global communication activity.

Data de submissão: 17/08/2016

Data de aceite: 03/10/2016 